\title{
Strangle hernia in the children! not always, amyand hernia with appendicitis
}

\author{
M Lahfaoui*, E Koulouris, A Alfaour and L Gouizi \\ Service De Chirurgie Pediarique, C.H. Delafontaine, Paris, France
}

Received: 24 April, 2020

Accepted: 15 May, 2020

Published: 16 May, 2020

*Corresponding author: M Lahfaoui, Service De Chirurgie Pediarique, C.H. Delafontaine, Paris, France, Email: simo88_6@hotmail.com

Keywords: Amyand's hernia; Appendicitis; Children; Herniotomie

https://www.peertechz.com

Check for updates

\begin{abstract}
The diagnosis of acute appendicitis is sometimes difficult to make. Among the atypical presentations is Amyand's hernia. This is the development of acute appendicitis within an abdominal hernia. Amyand's hernia is a rare but important disease to know. This pathology bears the name of the English surgeon, Claudius Amyand, operator of the first appendectomy in the history of medicine in 1735, performed for an acute appendicitis inside an inguinal hernia. Here we present a case of Amyand's hernia in a 2-month-old male, who presented as a right-sided congenital hernia with pain in the right groin. He underwent herniotomy, which revealed that the hernia sac containing inflamed appendix.
\end{abstract}

- Rare pathology

- Very high risk of misdiagnosis: Strangulated hernia.

- The knowledge of this pathology reduces the surprise effect which directly affects the results of the surgery and the postoperative follow-up.

- The article allows to better know the ideal surgical management through a rich discussion (14 references).

\section{Introduction}

The description of an abdominal hernia can take into account two factors: either the location or the content of the hernia. If the hernia is described according to the location, we can call inguinal, femoral, Spigel, obturator, lumbar, sciatic, diaphragmatic or incisional hernias. Three types of hernia have been described according to their content: Littré's hernia (contains a Meckel diverticulum), Richter's hernia (contains an antimesenteric part of the small intestine) or Amyand's hernia [1]. The latter contains an acute appendicitis and was named in memory of Claudius Amyand, author of the first appendectomy performed in the history of medicine in 1735, at St George's Hospital in London, for acute appendicitis within an inguinal hernia [2].

\section{Cas report}

This is a 2-month-old patient with a history of reducible right inguino-scrotal hernia, admitted for management of right inguino-scrotal swelling of irreducible inflammatory appearance (Figure 1) for 6 hours prior to admission, associated with vomiting and transit disorder, with a fever of 38.7.0n general examination, the infant was hemodynamically and respiratorily stable, and on objective local examination there was right inguino-scrotal swelling of irreducible inflammatory appearance with redness and a testis that was not palpable on the right due to local edema (Figure 1). No abnormalities were noted on the biologic (WBC: $10,3 \times 10^{9} / \mathrm{L}, \mathrm{CRP}: 5 \mathrm{mg} / \mathrm{L}$ ) and radiologic work-up. The patient was taken to the operating room for management of a strangulated inguinal hernia.

Intraoperatively the body of the appendix were stuck to the hernia sac. The appendix was perforated with an inflamed distal part (Figure 2). The base of the appendix and the cecum were normal and the testis was viable. An appendectomy and closure of the hernial sac was performed. The patient received 3 days of cefoxitin $80 \mathrm{mg} / \mathrm{kg} /$ day. The postoperative sequelae were uneventful. No complications were noted.

\section{Discussion}

The positional variations of the cecum and appendix allow 
the appendix to reach almost all abdominal hernial orifices. Thus, the discovery of appendicitis inside a hernia obturator $[3,4]$, Spigel's [5,6], umbilical [7], diaphragmatic, intrathoracic [8-10], incisional [11] or in a laparoscopic trocar port [12] has been described. Right inguinal and femoral hernias are the most common site for the development of an Amyand's hernia, but this entity has also been described on the left side [13]. Among

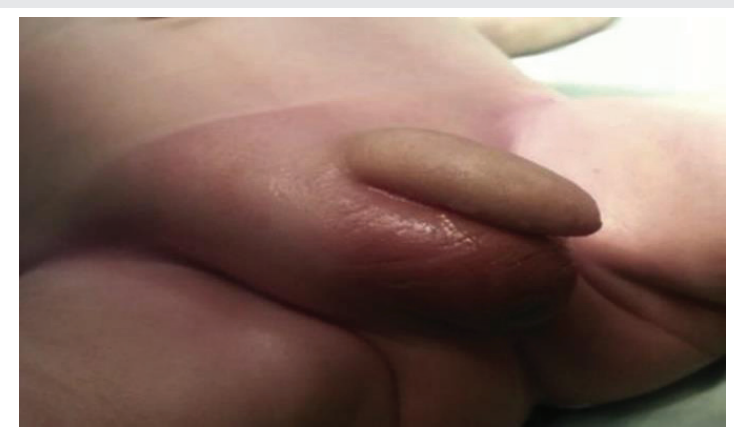

Figure 1: Right inguino-scrotal swelling with an inflammatory appearance.

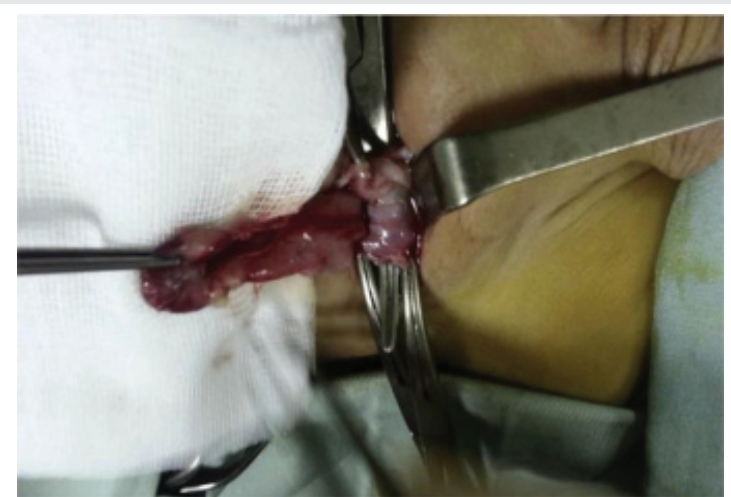

Figure 2: Intrahernal appendicitis.

incarcerated hernias containing viscera, the presence of the appendix is estimated to be $1 \%[14,15]$. The development of acute appendicitis within a hernia sac (Amyand's hernia) is estimated to be $0.13 \%$ of all appendicitis [14].

The clinical presentation of an Amyand's hernia is that of a strangulated hernia, that is, the development of a nonreducible inguinal arch, but without digestive occlusion. An inflammatory syndrome may develop depending on the course of acute appendicitis [16].

The diagnosis of Amyand's hernia is difficult to make and is often discovered intraoperatively if surgery is decided quickly. Delay or failure to treat can be fatal. Indeed, Carrey described a mortality rate of three out of ten patients with Amyand's hernia in the 1960s [13]. Today, diagnostic capabilities have improved significantly and computed axial tomography (CT) scans are available for preoperative diagnosis $[17,18]$ (Figure 3).

Surgically, when a non-inflamed appendix is discovered during elective hernia repair, it is advisable to perform an inguinal appendectomy and hernia repair without the use of prosthetic material because of the risk of bacterial

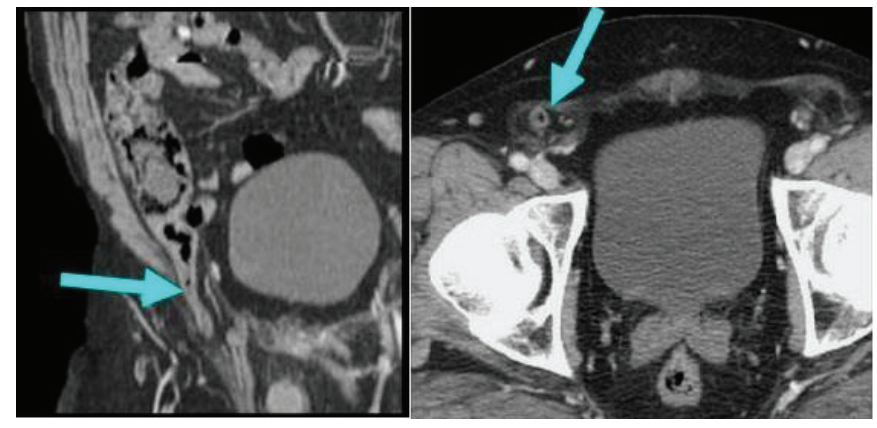

Figure 3: CT image objectivizing an intrahernal appendicitis [17,18].

contamination $[1,16,19]$. In the case of Amyand's hernia with acute appendicitis, the surgeon will also perform an inguinal or abdominal appendectomy if the periapendicular inflammation is extensive. The cure of the hernia will of course be done without prosthetic material.

A non-reducible incarcerated hernia is a surgical emergency and must be operated on as soon as possible. In case of unavoidable delay, an attempt to reduce the hernial sac must be a considered gesture. Indeed, it is possible to reduce the hernia en bloc with its hernia ring allowing a continuation of the intestinal suffering intra-abdominal with risk of perforation and peritonitis. An attempt of gesture must be carried out by an experienced surgeon, with the possibility of a close clinical supervision and if necessary an emergency intervention.

\section{Conclusion}

Amyand's hernia is a rare but important disease to know. Its clinical picture is similar to that of a strangulated hernia. Amyand's hernia generally has a good prognosis, although serious complications have been described. So a surgeons must be prepared to avoid the effect of surprise and ensure adequate care without further complications.

\section{Ethical considerations}

The patient's parents confirmed the patient's approval

\section{References}

1. Hutchinson R (1993) Amyand's hernia. JR Soc Med 86: 104-105. Link: Link: https://bit.ly/3dBayjo

2. Amyand $C$ (1736) Of an inguinal rupture, with a pin in the appendix coeci, incrusted with stone; and some observations on wounds in the guts. PhilosTr R Soc London 39: 329-342. Link: https://bit.ly/35Zylla

3. Archampong EQ (1969) Strangulated obturator hernia with acute gangrenous appendicitis. BMJ 1: 230. Link: https://bit.ly/2WsPC8k

4. Hartley BE, Davies MS, Bowyer RC (1994) Strangulated appendix in an obturator hernia presenting as gas gangrene of the thigh. Br J Surg 81: 1135. Link: https://bit.ly/2xXFzPc

5. Lin PH, Koffron AJ, Heilizer TJ, Lujan HJ (2000) Right lower quadrant abdominal pain due to appendicitis and an incarcerated spigelian hernia. Am Surg 66: 725-727. Link: https://bit.ly/2Z8nqt4

6. Carr JA, Karmy-Jones R (1998) Spigelian hernia with Crohn's appendicitis Surg Laparosc Endosc 8: 398-399. Link: https://bit.ly/2zB74yy 
7. Doig CM (1970) Appendicitis in umbilical hernial sac. BMJ 2: 113-114. Link: https://bit.ly/3cC4KGo

8. Gurses N, Gurses N (1986) Perforating appendicitis within a diaphragmatic hernia: A case report. Z Kinderchir 41: 306-307. Link: https://bit.ly/3bt1Emn

9. Sepehri A (1980) Acute appendicitis within a diaphragmatic hernia (author's transl). Chirurgie 106: 315-317. Link: https://bit.ly/3bqjJ4E

10. Zerin JM (1990) Intrathoracic appendicitis in a ten-year-old girl. Invest Radiol 25: 1162-1164. https://bit.ly/2zGy7IH

11. Horgan PG, O'Donoghue J, Courtney D (1991) Perforated appendicitis in an incisional hernia. Ir J Med Sci 160: 350-351. Link: https://bit.ly/2WYftnG

12. Bamberger PK (2001) Revisiting Amyand's hernia in the laparoscopic era Surg Endosc 2001 ; 15: 1051. Link: https://bit.ly/2LrJsPE

13. Carey LC (1967) Acute appendicitis occurring in hernias: A report of 10 cases Surgery 1967 ; 61: 236-8. Link: https://bit.ly/35VcDnJ
14. Ryan WJ (1937) Hernia of the vermiform appendix. Ann Surg 106: 135-139.

15. Srouji MN, Buck BE (1937) Neonatal appendicitis: Ischemic infarction in incarcerated inguinal hernia. $\mathrm{J}$ Pediatr Surg 13: 177-179. Link: https://bit.ly/2Ls7BFH

16. Logan MT, Nottingham JM (2001) Amyand's hernia: A case report of an incarcerated and perforated appendix within an inguinal hernia and review of the literature. Am Surg 67: 628-629. Link: https://bit.ly/35Za18i

17. Zissin R, Brautbar O, Shapiro-Feinberg M (2000) CT diagnosis of acute appendicitis in a femoral hernia. $\mathrm{Br} \mathrm{J}$ Radiol 73: 1013-1014. Link: https://bit.ly/2SYg6wv

18. Luchs JS, Halpern D, Katz DS (2000) Amyand's hernia: Prospective CT diagnosis. J Comput Assist Tomogr 24: 884-886. Link: https://bit.ly/2T33yDQ

19. Ofili OP (1991) Simultaneous appendectomy and inguinal herniorrhaphy could be beneficial. Ethiop Med J 29: 37-38. Link: https://bit.ly/2T5EUm6
Discover a bigger Impact and Visibility of your article publication with Peertechz Publications

\section{Highlights}

* Signatory publisher of ORCID

* Signatory Publisher of DORA (San Francisco Declaration on Research Assessment)

* Articles archived in worlds' renowned service providers such as Portico, CNKI, AGRIS TDNet, Base (Bielefeld University Library), CrossRef, Scilit, J-Gate etc.

* Journals indexed in ICMJE, SHERPA/ROMEO, Google Scholar etc.

* OAI-PMH (Open Archives Initiative Protocol for Metadata Harvesting)

* Dedicated Editorial Board for every journa

* Accurate and rapid peer-review process

* Increased citations of published articles through promotions

* Reduced timeline for article publication

Submit your articles and experience a new surge in publication services (https://www.peertechz.com/submission).

Peertechz journals wishes everlasting success in your every endeavours.

Copyright: (C) 2020 Lahfaoui M, et al. This is an open-access article distributed under the terms of the Creative Commons Attribution License, which permits unrestricted use, distribution, and reproduction in any medium, provided the original author and source are credited 